\title{
Civilising offensives and ambivalence: the case of British Gypsies
}

\author{
Ryan Powell* \\ Sheffield Hallam University
}

\begin{abstract}
This paper utilises Norbert Elias's theory of the civilizing process to examine British society's response to Gypsies and explore the perception of this group as in "need of corrective treatment'. It demonstrates how state policies towards Gypsies are presented as improving their welfare but are in fact characterised by ambivalence. It is argued that mechanisms employed with the expressed goal of 'civilising' behaviour actually exhibit decivilising elements in terms of their effect upon Gypsy culture. The paper concludes by pointing to the concept of a civilising offensive, a deliberate civilising project targeting Gypsies, as a means of elucidating the oppressive and damaging nature of policies towards them and their cultural continuity.
\end{abstract}

Key words: Elias, civilising processes, civilising offensives, ambivalence, Gypsies.

\section{Introduction}

Historically, the response of British society to Gypsies has involved a diverse range of attitudes and measures which have altered alongside the development of wider society. Approaches have been characterised by barbaric practices, punitive measures and draconian legislative policies including: extermination and expulsion (Mayall, 1988); mechanisms to encourage modernisation and assimilation (Sibley, 1986; 1987); discrimination; criminalisation (Mayall, 2004); and social control (Halfacree, 1996; Richardson, 2006; Sibley, 1988). Similarly, the everyday social relations between Gypsies and the settled population are often shaped by conflict and antagonism, both historically and in more recent times. Such negative relations have given rise to, and at the same time maintained and perpetuated, processes of disidentification and stigmatisation (Powell, 2008). The recurring theme throughout these historical responses has been the negative and imagined image of Gypsies which has both informed and been reinforced by the 
actions of the state. Notions of a lack of morals and self restraint, dirt, violence, deviance, laziness, illiteracy and racial purity ("real" Gypsies) have all been used at different times to justify discriminatory responses to Gypsies, with these attributed characteristics constructed in opposition to the values of 'respectable' society. Thus arguments to justify the enforcement of conformity and sedentarisation were modified over time (Mayall, 1988, p.185) with these modifications taking place against a backdrop of social change which brought about an increasingly differentiated society.

While the arguments to justify and legitimise oppressive state policies towards Gypsies have altered as wider society has developed there is a commonality in both historical and contemporary representations and perceptions of Gypsies. Central to their stigmatisation and marginality is the idea that as a group, Gypsies are of lesser human worth (for whatever reason is pertinent at the time) and their behaviour is characterised by incivility in contrast to the high standards of manners and refinement attained by the middle classes of the developed West. Gypsies and their way of life have been constructed in opposition to civilisation: a civilisation based on, and an expression of, the dominant world-view of the Western middle classes.

This paper argues that the connected negative representations, popular perceptions and British state policies can be better understood with reference to Norbert Elias's theory of the civilizing process and specifically the concept of the ambivalence of human relations and the notion of civilising offensives - which has been subsequently developed by Eliasian scholars. Firstly, the paper considers the theoretical work of Elias as a framework with which to explore the historical response to Gypsies in its broadest sense. It is argued that Elias's figurational sociology, with its emphasis on power and changes in people's sensibilities, has much to offer here. Secondly, the notion of the 'civilising offensive' is utilised and shown to be an illuminating theoretical concept when considering the long term development of the relations between 'established' and 'outsider' groups.

Thirdly, the paper briefly recounts some of the different historical representations and images of British Gypsies from the sixteenth century onwards pointing to the persistence of stereotypes which are deemed incompatible with, and a threat to, the social order and standards of conduct of the dominant society at different stages of development. The focus here is on group relations and the ways in which Gypsies have been constructed as 'barbaric' or at odds with the 'civilised' sedentary mode of existence of the dominant society; and the outcomes of this in terms of the fantasy-laden images which characterise the public perception of them as a collective group. As such the state is but one actor in the civilising offensive and analysis must extend beyond the state to take account of general societal developments and the subtle changes in people's sensibilities.

To this end, historical representations are then considered alongside state policies, approaches and attitudes towards Gypsies in order to illustrate the ways in which long-term changes in people's sensibilities are expressed in, and shape, the actions of the state. The ambivalence inherent in these relations is also discussed and it is argued that policies which have been put in place with the expressed goal of 'civilising' the behaviour of Gypsies have actually produced decivilising results in terms of the cultural violence bestowed upon the Gypsy population. The three examples of pressures towards sedentarisation, education and settlement control are used to briefly illustrate the manifestation of the civilising offensive in state action. Indeed, it is argued that often the very mechanisms of different civilising offensives against Gypsies are themselves an expression of a decivilising process in terms of a departure from the overall long-term direction of state policies towards more 
p. 114. Civilising offensives and ambivalence: the case of British gypsies

ameliorative and pluralistic approaches. While approaches towards Gypsies show a discernible civilising trend over the long term as society has become more civilised, it is argued that ambivalence is central to an understanding of continued oppressive policies which are presented as being in the welfare interests of the population.

\section{The Civilizing Process}

The Civilizing Process (Elias, 2000) focuses on changes in human behaviour, power and habitus and situates long term transformations in the standard of human conduct from the medieval period onwards alongside the wider development of society. In other words, standards of behaviour in face-to-face interaction, psychological and emotional make-up are conditioned by broader social processes (Fletcher, 1997, p.21). The civilizing process is closely linked to the process of state formation and particularly the emergence of the absolutist state and the resultant monopolisation of violence (and later threat of violence) leading to the internal pacification of society. In contrast to the medieval period the use of violence is therefore more calculable, society less dangerous, and through foresight and reflection the individual can restrain his or her behaviour.

With the development of the urban mode of life society has gradually become more differentiated and complex and the webs of interdependence that link individuals, groups and nation-states together have increased and lengthened leading to increased integration over the long-term. For Mennell (1990) key processes inherent in these changes include: the division of labour; the growth of trade; urbanisation; monetarisation; increasing administration; and an increasing population. Changes at the social level have then impacted upon the psychological make-up of individuals, setting in train a process of psychologisation whereby 'more people are forced more often to pay more attention to more other people' (Goudsblom, quoted in Mennell, 1990, p.209). This gradual process is at once individual and social and only discernible over the long-term as social constraints are very slowly transformed into self constraints within the individual, and shame and embarrassment are elevated to the 'master emotions' (Scheff, 2004) controlling human behaviour. In Elias's words:

'People, forced to live with one another in a new way, became more sensitive to the impulses of others. Not abruptly but very gradually the code of behaviour became stricter and the degree of consideration expected of others became greater. The sense of what to do and what not to do in order not to offend or shock others became subtler, and in conjunction with the new power relationships the social imperative not to offend others became more binding' (Elias, 2000, p.69).

The psychologisation process is related to processes of functional democratisation and mutual identification as we think more about the consequences of our actions for others.

Kilminster (1998, p.149) describes functional democratisation as the process of relative social levelling that has taken place at a deep level in modern societies over several centuries' and he continues by describing it as the 'long-term, unplanned process of the lessening of the power gradients and social distance between interdependent groups in societies that have become increasingly differentiated' (ibid: 151). As this process continues the scope for mutual identification increases as individuals and groups 
p. 115. Civilising offensives and ambivalence: the case of British gypsies

are bonded together more tightly leading to increased interdependencies (see de Swaan, 1995).

The important factor to note for the discussion that follows is that different sensibilities have developed in different societies as a result of long term social processes which take a particular, though unplanned, direction. This change is not smooth or unilinear but shows fluctuations and short-term changes of direction which follow smaller and shorter curves (Fletcher, 1997, p.14). Coupled with the concept of ambivalence, it is this feature of civilizing processes, the nuances and subtleties within the overall direction of society towards a more 'civilised' standard, which helps to explain how supposedly 'civilised' societies and states, and the projects carried out in the very name of 'civilisation' can be barbaric.

\section{Civilising Offensives: Civilisation as the 'self-consciousness of the West'}

In the opening pages of The Civilizing Process Elias states that the general function of the term 'civilisation' is that 'the concept expresses the self-consciousness of the West' $(2000$, p.5). In this sense 'civilisation' describes 'a process ... It refers to something which is constantly in motion, constantly moving "forward"' $(2000$, p.6). In other words, there is no absolute beginning of civilisation; no society is uncivilized. 'The civilization which we are accustomed to regard as a possession that comes to us ready-made, without our asking how we actually came to possess it, is a process or part of a process in which we ourselves are involved' (Elias, 2000, p.52). Furthermore, 'to a certain extent the concept of civilization plays down the national differences between peoples; it emphasizes what is common to all human beings or - in the view of its bearers - should be' (2000, p.7 - my emphasis).

Towards the end of the eighteenth century, civilisation became infused with two central ideas: first, it stood as a courtly concept in opposition to 'barbarism'; and second it constituted the notion of progress with a goal: 'Anything from trade to education, within which barbaric practices could be discerned, came under the province of reform in the name of civilisation, involving the refinement of manners and the internal pacification of the country by the kings' (Elias, 2000, p.41). This formed part and parcel of what has been described as a 'civilising offensive' (Fletcher, 1997, p.9). Reform in the name of civilisation applied equally to the subjects within one's own territory who had yet to 'achieve civilisation' in the eyes of the middle classes as it did to the colonial project. Thus, to the middle-classes of the West the concept of civilisation indicates that the process of civilization had been completed and forgotten:

'People only wanted to accomplish this process for other nations, and also, for a period, for the lower classes of their own society. To the middle classes of their own society, civilization appeared as a firm possession. They wished above all to disseminate it, and at most to develop it within the framework of the standard already reached' (Elias, 2000, pp.88-89).

Yet as Elias states "our terms "civilized" and "uncivilized" do not constitute an antithesis of the kind that exists between "good" and "bad", but represent stages in a development which, moreover, is still continuing' (p.52). This feature of Elias's conception has particular resonance when seeking to understand the barbaric actions of nation-states carried out 
p. 116. Civilising offensives and ambivalence: the case of British gypsies

with the explicit goal of 'improving' or 'correcting' the social conduct and cultural practices of certain sections of the population deemed to be less civilised. The point is that civilisation, when understood as the self-consciousness of the West, was (and still is) something which the middle classes wish to give to those they consider 'barbarous' and 'uncivilised'. The discussion that follows illustrates how this civilising project is at least ambivalent and at worst barbaric.

\section{Civilising Offensives and Ambivalence}

The Civilizing Process is interpreted by some scholars as a progress theory and Elias is often criticised for the lack of attention given to decivilising processes (Burkitt, 1996; van Krieken, 1999; Vaughan, 2000). Another criticism stems from the blind, unplanned nature of civilising processes and the 'automatism of Elias's formulations' which ignore the instances where civilisation has been 'steered' in a particular direction (van Krieken, 1999, p.303). The concept of the civilising offensive, developed by Eliasian scholars, addresses these critiques and is able to account for the deliberate attempts at inculcating lasting ('civilised') habits on the part of powerful groups in relation to 'outsider' groups.

While discussion of decivilising processes may be absent from the two volumes of The Civilizing Process, Elias did stress the latent ambivalence of human relations, arguing that it is a special quality which manifests itself more strongly the broader and denser the network of social interdependence becomes (Elias, 2000). Where such interdependencies are present he writes: "All people, all groups, estates or classes, are in some way dependent on one another; they are potential friends, allies or partners; and they are at the same time potential opponents, competitors or enemies' (Elias, 2000: 317). For Elias this latent ambivalence is: "one of the most important structural characteristics of more highly developed societies, and a chief factor moulding civilized conduct' (ibid: 318). The importance of ambivalence is recognized by van Krieken for whom the ambivalent character of social relations is just as important as the increasing webs of interdependence which are central to Elias's developmental approach. Thus, a central question for him is the ways in which nation-states have established a brutal and violent relationship between their own 'civilisation' and the supposedly 'barbaric' cultures of subjected peoples (1999, p.302).

'Just as important as the 'length of chains' was the increasing ambivalence of overlapping and multiple networks: as social relations become more complex and contradictory, the same people or groups could be 'friends, allies or partners' in one context and 'opponents, competitors or enemies' in another (van Krieken, 2005, p.42 - my emphasis)

This ambivalence of interests coupled with the idea of civilisation as a possession of the developed societies of the West led the way for the civilising offensive.

Ambivalence has also been cited as a central factor in the application of the civilising process to the penal system (Garland, 1991; Franke, 1992; Pratt, 1998; Vaughan, 2000). Pratt (1998) charts the changing public sentiment with regards to the penal agenda and the different attitudes, at different stages of development, towards punitive measures. He observes an increase in sympathy towards the suffering of prisoners over the long-term 
with counter-trends in public sentiment enabling the re-emergence of more 'barbaric' measures within the penal system at particular phases of development.

The academic debates played out in relation to the (de)civilising of punishment are helpful in highlighting the importance of the development of sensibilities and how this is reflected in public policy (see Garland, 1991). However, in terms of the focus here, that is the state's civilising project against Gypsies, it is useful to turn to van Krieken's (1999) work on the Australian state's response to the indigenous population and what he terms 'the systematic removal of indigenous Australian children from their families' (this has also been cited as an extreme stance proffered with respect to Gypsy children in the nineteenth century in Britain (Vanderbeck, 2005, p.78)) which was made possible through legislation passed in the early twentieth century. The Australian state's approach included the governance of Aboriginal movements and the 'rescue' of the rising generation by forcible removal from their families. Absorption and assimilation into the ways of civilisation were the key concepts around which this discourse was organized (van Krieken, 1999, p.307). For van Krieken the firm belief that this policy was contributing to the welfare of the indigenous population raises the possibility that civilisation and decivilisation interpenetrate so that 'societies are barbaric precisely in their movement towards increasing civilization' (van Krieken, 1999, p.297). Like Burkitt (1996) he argues that civilisation should be seen as an inherently ambivalent process with the potential to unleash barbaric forces on a large scale. This ambivalence is expressed and clearly discernible in the concept of the civilising offensive:

'it is important to supplement, systematically, the concept of civilizing processes with that of civilizing offensives, to take account of the active, conscious and deliberate civilizing projects of both various powerful groups within societies and whole societies in relation to other regions of the world' (van Krieken, 1999: 303 my emphasis).

van Krieken himself highlights the similarity with the 'logic of governance' of the nonrespectable working class but the same can also be said of approaches towards Gypsies. The Australian state's response to Aborigines shares some similarities with historical approaches to what has been constructed in both official and popular discourse as the 'Gypsy problem'. As is the case with indigenous Australians, the view that Gypsies are in need of corrective treatment is long standing with Gypsies seen as 'potentially available for change and rescue from what is seen by non-Gypsies as a lost future' (Okely, cited in Vanderbeck, 2005, p.72). van Krieken posits that the reality of interbreeding threatened the very boundaries of civilisation itself such that 'everything that civilization was meant to have achieved, a distance between the present and the past, was thrown into disarray' (1999, p.305). Consider the respective perceptions of first Aborigines and secondly that of Gypsies:

'...they were regarded as representing precisely those forms of behaviour which the civilizing process was meant to have overcome, the 'repressed' of modern civilization - idleness, nomadism, emotionality, lack of discipline and productivity, sexual promiscuity, poor bodily hygiene, and a group rather than an individual orientation' (van Krieken, 1999, p.305)

'...nomads were seen as offering the worst face of an unacceptable society with their lawlessness, heathenism, promiscuity and barbarism ... what is more this 
p. 118. Civilising offensives and ambivalence: the case of British gypsies

section of the population presented the amoral face of an uncivilised society, lacking any religion, ignoring acceptable codes of decency and engaging in all forms of promiscuous behaviour' (Mayall, 2004, p.60).

Both accounts draw attention to the centrality of social conduct in the image of the two groups and the perceived failure to observe the 'civilised' standards of the dominant society. Thus, both indigenous Australians and British Gypsies have been collectively stigmatised and the perception of these outsider groups, based on stereotypical and fantasy-laden generalisations, has been at odds with the Western understanding of civilisation. As the concept of civilisation took root towards the end of the eighteenth century so too did the idea that the rescue of classes and groups yet to attain the standards of 'civilised' society should be a goal of the state. Where such groups were considered a threat to the social order, this goal was all the more imperative.

\section{British Gypsies and the civilising offensive}

As mentioned above, the civilising offensive against Gypsies is not limited to the role of the state: one must also take account of general societal developments and attitudes which contextualise the actions of the state. Furthermore, these attitudes are not static but change in subtle ways alongside structural changes in society. It is therefore necessary to consider historical representations and approaches before turning attention to the examples of the manifestation of the civilising offensive in the actions of the state.

The first legislation specifically aimed at Gypsies (or Egyptians as they were then termed) was passed in 1530 under the reign of Henry VIII (Mayall, 2004). Historically, they have been subsumed within a diverse category of outsider groups who share a nomadic orientation and as such joined 'a migrant and itinerant population of early modern England that was diverse, fluid and periodically very numerous' (Mayall, 2004). The perceived presence of large numbers of itinerants was considered as much a social problem in the seventeenth century as it was at the height of modernity and the consistently hostile response has reflected this. Mayall puts the oppressive actions of the King at this time down to the increasing numbers of vagrants, rogues and vagabonds on the one hand, but gives more weight to the fact that they were masterless and nomadic and as such were seen to have broken with the 'family, economic, religious and political conventions' of the time:

'Equally important, the movement from bound to free labour, or no labour, meant that traditional social relations, and with them mechanisms of social control, were being broken down. Masterless men, at the political, economic and ideological levels, thus came to be perceived as a danger to the established order' (Mayall, 2004, p.58).

Gypsies became subsumed within the catch-all category of vagrants, the response to which can be seen as a counter to the criminal activities of some of this population, but this also served to criminalise previous activities through the erection of all-embracing categories (Mayall, 2004, p.63). Thus previously legitimate practices which Gypsies were engaged in, such as fortune telling for instance, were made illegal. 
From the initial categorisation of Gypsies alongside the general itinerant population there developed a more nuanced understanding from the eighteenth century onwards 'allegedly based on empiricist objectivity derived from fact-finding missions to the Gypsies' camps' (Mayall, 1988, p.185). The same period witnessed the emergence of the concept of civilisation to take on the meaning outlined above and subsequently the 'Gypsy problem' came under 'the province of reform in the name of civilisation'. The remainder of this section of the paper briefly points to three areas where the civilising offensive has taken root in relation to Gypsies: pressures towards sedentarisation; education; and settlement control.

\section{Sedentarisation}

One clear and visible opposition to the notion of civilised society in the eyes of the Western middle classes is nomadism. McVeigh (1997) argues that the sedentarised character of Western societies inevitably 'pathologises and represses nomadic modes of existence' which are viewed as a threat to the social order. The fact that sedentarism is an ingrained way of life for the majority makes nomadic groups appear alien; living outside social norms. 'The continued existence of nomads and vagrants was a key symbol of the unfinished project of modernity and evidence of the survival of unwanted elements from the premodern' (McVeigh, 1997, p.18). McVeigh observes a change in the level of discourse through time but argues that the outcomes in terms of an erosion and even 'genocidal' effect on Gypsy culture are the same as previous, more overtly barbaric practices: 'extermination and expulsion are solely concerned with the interest of sedentaries while assimilation is presented as being in the interest of sedentaries and nomads' (ibid, p.23). There is a commonality in the goal of both in terms of the eradication of the 'Gypsy problem' and in this respect McVeigh sees assimilation as little different from extermination. Thus, though assimilation is not explicitly barbaric in the way that previous approaches were, the affect on culture and the inherent ambivalence of assimilationist policies are clearly within the framework of the civilising offensive.

\section{Education}

Vanderbeck (2005) argues that contemporary discourses, while perhaps more subtly expressed than in the past, construct young Travellers as 'needing greater interaction with mainstream schooling' which often reflects 'long standing notions of cultural disadvantage and deficit' (p.75). He also posits that children's rights discourses often construct 'Traveller parents as obstacles to their children's development and well-being, and thus serve to legitimise various forms of state intervention and exertions of power' (ibid: p.73). Similarly, Sibley $(1986 ; 1987)$ highlights the inappropriate conceptions of modernisation theories with regards to Gypsies and shows that the supposedly inevitable outcome of acculturation to the modern society and resultant integration is a particularly ethnocentric view. Such perspectives ignore traditional practices and emphasise interaction with mainstream institutions such as schools over other experiences such as work which may be deemed of more value within Gypsy society (Sibley, 1981). Indeed, formal institutional contact has been one of the mechanisms through which the state has tried to absorb and assimilate Gypsies and Travellers but this has been at odds with cultural and traditional norms. Thus a 1963 Report by the Irish Commission on Itinerancy stated that education was 'urgently necessary as a means of providing opportunities for a better way of life and of promoting their absorption into the settled community' (cited in ni Shuinear, 1997, p.40). 
For Gypsies and Travellers active in the traditional trades, however, formal schooling is deemed less important than the dissemination of knowledge and skills required to earn a living. This also acts as a form of cultural continuity with certain economic practices bound up with Gypsy identity. Thus, as Vanderbeck (2005) has argued, education is a realm in which narrow Western conceptions of childhood ignore Gypsy culture, and particularly the different notion of learning. This has resulted in the idea that state intervention, framed by the imposition of the Western concept of childhood, is required in order to 'save' Gypsy children.

\section{Settlement Control}

The third policy example which represents a manifestation of the civilising offensive against Gypsies is that of settlement control. The control of Gypsy movements through policies such as the 1968 Caravan Sites Act and the 1994 Criminal Justice and Public Order Act has served to accentuate the difficulties of cultural continuity; and of those faced by Gypsies engaged in traditional employment: the ability to travel and stop freely in order to sell and trade has been restricted. Moreover, the Caravan Sites Act is a good example of the ambivalence of policies towards Gypsies. As Sibley notes, the Act was "widely interpreted as liberal legislation which would enable the Traveller community to continue a nomadic way of life but...it would be more appropriate to see the Act as a programmed response to deviance' (1987, p.82). Presented as a favourable development to the travelling community the policy actually exempted many urban local authorities from providing sites; and imposed financial penalties on any family stopping in a designated area but not on an official site. Consequently the movements of Travellers were greatly restricted increasing the difficulties of following a nomadic lifestyle.

Sibley (1987) compares the cases of British Gypsies with the experiences of the indigenous populations of Australia and North America finding parallels in terms of the way that settlement control has been a feature of policy and part of a strategy of social control as defined by Cohen (1985): "a planned and programmed response to expected and realized deviance' (p.2 cited in Sibley, 1987, p.76). Central to such policies is the desire to disperse, contain and, most importantly, to transform (Sibley, 1987, p.76). This certainly resonates with the discussion above on civilising offensives. He points out that to the larger society the Gypsy way of life appears disordered but in fact this is just 'a different kind of order reflecting the integrated nature of Gypsy culture. The idea of a spatial separation of work, residence and recreational activities is alien to Gypsies' while their integration is 'a form of deviance according to a dominant world-view' (Sibley, 1987, p.77).

From this brief discussion of representations of, and resultant policies against, Gypsies it is clear that from the arrival of the first Gypsies in England, images and constructions of them as a collective group have been at odds with the dominant society and a threat to it, giving rise to 'intense persecution, prosecution and harassment' (Mayall, 1995, p.43). Mayall contends that successive Kings and subsequently the British state have "viewed Gypsies as persistent and irritating thorns in their flesh' from the sixteenth century on due to their apparent 'defiance of the laws of the land and of contemporary trends to sedentarisation and civilisation' (1995, p.88). This perceived defiance of the laws and engagement in practices and behaviour outside the norms of society was given new impetus with the emergence of the absolutist state and the concept of civilisation in the eighteenth century. Indeed, it is from this point that one can discern a change in 
p. 121. Civilising offensives and ambivalence: the case of British gypsies

approaches towards Gypsies: reframed along the lines of 'correction' rather than persecution.

\section{The (de)civilising of state policies towards Gypsies?}

The preceding discussion has provided some cursory examples of the state's response to Gypsies and situated these alongside the concept of civilisation to show how civilising offensives have been enacted against the stereotyped group and its imagined characteristics. It could be argued that approaches towards Gypsies have shown a civilising trend over the very long term, proceeding as they have from policies of extermination and expulsion to assimilation, absorption and acculturation linked to flawed ideas based on modernisation theory (Sibley, 1987). While the stereotypes, the perceived faults and fears may have changed as society has developed the key representations informing perceptions and policy from the turn of the nineteenth century onwards, have been the ideas of moral deficiency, the need for corrective treatment and the construction of the Gypsy way of life as inferior to the civilised mode of sedentary existence. Though overtly barbaric practices have receded alongside changes in people's sensibilities and processes of functional democratisation the state has continued to oppress the Gypsy population through policies which have eroded cultural practices such as nomadism and the pursuit of traditional employment opportunities.

What is striking is the fact that in spite of a concerted effort over several generations the different civilising offensives have essentially failed in their ambitious project to completely assimilate Gypsies into mainstream society. As Sibley has noted Gypsies adapt to the increased differentiation and interdependencies of society, and they do so in order to 'stay the same' (Sibley, 1987). Furthermore, the goal of assimilation is neither favourable nor possible. It is not favourable for obvious reasons: such cultural genocide represents a barbarism of the kind outlined by van Krieken (1999). Equally, attempts at changing behavioural norms and standards of conduct that have developed over centuries through complex and gradual processes of social competition, socialisation and psychologisation and which have inculcated lasting habits and advanced thresholds of shame and repugnance are evidently futile. Similar conclusions have also been drawn with regards to ambitious attempts to regulate and formalise the behaviour of other groups in contemporary society (see Flint, 2006; Flint and Nixon, 2006). In carrying out such civilising projects powerful groups (including state governments) aiming to change cultural practices and social conduct have failed to realise that increasing thresholds of shame and embarrassment did not come about through "consciously rational decisions of large groups of people...Rather, it is the unplanned dynamics of social competition and social interweaving that foster the development of “delicate" sensibilities' (Fletcher, 1997, p.15).

The theoretical concept of the civilising offensive is able to reveal the ways in which states (and other powerful groups) have attempted (and continue to attempt) to systematically eradicate certain cultures and forms of behaviour which are perceived as existing outside the social norms of the dominant ('civilised') society, a threat to the social order and, therefore, to the power base of established groups. In relation to the civilising project against Gypsies, the ambivalence of policies presented as improving their welfare requires further exploration and a much deeper analysis than has been possible here in order to assess the effect on cultural practices which are central to the continuation of Gypsy culture and identity. 
p. 122. Civilising offensives and ambivalence: the case of British gypsies

* Correspondence Address: Ryan Powell, Centre for Regional Economic and Social Research, Sheffield Hallam University, Unit 10, Science Park, Howard Street, S1 1WB, UK. Email: r.s.powell@shu.ac.uk.

\section{References}

Burkitt, I. (1996) Civilization and ambivalence. British Journal of Sociology, 47, 1, 135 150.

Cohen, S. (1985) Visions of Social Control. Cambridge: Polity Press.

de Swaan, A. (1995) Widening circles of identification: Emotional concerns in sociogenetic persepctive. Theory, Culture and Society, 12, 25-39.

Elias, N and Scotson, J. L. (1994) The Established and the Outsiders (2nd ed). London: Sage.

Elias, N. (2000) [1939] The Civilizing Process. (trans. by Edmund Jephcott). Oxford: Blackwell.

Fletcher, J. (1997) Violence and Civilization. Cambridge: Polity Press.

Flint, J. (2007, forthcoming) Tackling sectarianism: Scotland's respect agenda. Scottish Affairs.

Flint, J. and Nixon, J. (2006) Governing neighbours: Anti-social behaviour orders and new forms of regulating conduct in the UK. Urban Studies, 43, 5/6, 939-955.

Franke, H. (1992) The rise and decline of solitary confinement: Socio-hisorical explanations of long-term penal changes. British Journal of Criminology, 32, 2, 125-143.

Garland, D. (1991) Punishment and Modern Society. Oxford: Clarendon Press.

Halfacree, K. (1996) Out of place in the country: Travellers and the rural idyll. Antipode, 28, 1, 42-72.

Kilminster, R. (1998) The Sociological Revolution: From the Enlightenment to the Global Age. London: Routledge.

Mayall, D. (1988) Gypsy-Travellers in nineteenth century society. Cambridge: CUP.

Mayall, D. (1995) English Gypsies and state policies. Hatfield: University of Hertfordshire Press.

Mayall, D. (2004) Gypsy Identities 1500-2000: From Egipcyans and Moon-men to the Ethnic Romany. London: Routledge.

McVeigh, R. (1997) Theorising sedentarism: the roots of anti-nomadism, In: Acton, T. (ed) Gypsy politics and traveller identity, pp. 7-25. Hatfield: University of Hertfordshire Press.

Mennell, S. (1990) Decivilizing processes: theoretical significance and some lines of research. International Sociology, 5, 2, 205-223.

ni Shuinéar, S. (1997) Why do gaujos hate Gypsies so much, anyway? A case study, In: Acton, T. (ed) Gypsy Politics and Traveller Identity, pp. 7-25. Hatfield: University of Hertfordshire Press.

Okely, J. (1983) The Traveller-Gypsies. Cambridge: CUP.

Powell, R. (2008, forthcoming) Understanding the stigmatisation of Gypsies: Power and the dialectics of (dis)identification. Housing, Theory and Society.

Pratt, J. (1998) Towards the 'decivilizing' of punishment. Social and Legal Studies, 7, 487515.

Richardson, J. (2006) The Gypsy Debate: Can Discourse Control? Exeter: Imprint Academic. 
p. 123. Civilising offensives and ambivalence: the case of British gypsies

Scheff, T. J. (2004) Elias, Freud and Goffman: shame as the master emotion, In: Loyal, S. and Quilley, S. (eds) The Sociology of Norbert Elias.

Sibley, D. (1981) Outsiders in Urban Societies. Oxford: Blackwell.

Sibley, D. (1986) Persistence or change? Conflicting interpretations of peripheral minorities. Environment and planning D: society and space, 4, 57-70.

Sibley, D. (1987) Racism and settlement policy: the state's response to a semi-nomadic minority, In: Jackson, P. (ed) Race and Racism. London: Unwin Hyman.

Vanderbeck, R. (2005) Anti-nomadism, institutions, and the geographies of childhood. Environment and planning D: society and space, 23, 71-94.

Vaughan, B. (2000) The civilizing process and the janus-face of modern punishment. Theoretical Criminology, 4, 1, 71-91.

van Krieken, R. (1999) The barbarism of civilization; cultural genocide and the 'stolen generations. British Journal of Sociology, 50, 2, 297-315.

van Krieken, R. (2005) The 'best interests of the child' and parental separation: on the 'civilizing of parents. Modern Law Review, 68, 1, 25-48. 